\title{
CONSIDERATIONS IN THE SEARCH AND EXPLORATION FOR MINERALS IN BRITISH COLUMBIA
}

\begin{abstract}
JOHN R. MACKAY*
In the following article, Mr. Mackay discusses the acquisition and development of a mineral property under the provisions of the Mineral Act of British Columbia. The writer reviews three main types of agreements (and the more important terms of the various agreements) used for the acquisition of an "interest" in a mineral claim. Financing is a requisite of any exploration and development activity, and the author examines various sources of funds available for financing in the mining industry, concentrating on the most common method, incorporating a company to take over the development of the mining property, with particular emphasis on the various procedural steps which must be followed before a public offering can be made. Finally, Mr. Mackay briefly examines the problem of placing a mineral property into commercial production.
\end{abstract}

\section{INTRODUCTION}

I have been asked to discuss a "mining deal" from grubstake to production. Few "mining deals" ever reach production and, in fact, it has been estimated that for every 1,000 mining properties explored or investigated only one becomes a producing mine. Some statistics in respect of mining activity in British Columbia which you might find interesting are referred to in the following paragraphs.

During the past few years there has been an average of approximately 60,000 mineral claims located and recorded each year. Some 800 separate properties were under investigation last year and the amount of money spent and recorded with the government in respect of this investigation or exploration was about $\$ 11,000,000$. Because only that mining work which is necessary to maintain mining claims in good standing is recorded with the government, the actual amount spent last year is probably between $\$ 25,000,000$ and $\$ 30,000,000$.

Notwithstanding the large number of properties under investigation each year and the amount of money spent thereon, there were only 66 mines shipping or treating ore in 1970 and of these 10 mines accounted for $90 \%$ of such ore.

A logical starting point for this paper is a brief discussion of the Mineral Act of British Columbia ${ }^{1}$ which sets the framework within which most mining activity must be carried out. Following this, the writer has dealt with prospecting for minerals, the acquisition of mineral claims or an "interest" therein, discussed some of the more usual forms of agreement by which the "interest" is acquired and touched upon the exploration and development of mineral claims. The British Columbia Department of Mines considers that exploration is all work up to the time when the company declares its intention of proceeding to production and thereafter all work becomes development. As the raising of necessary funds to carry out the exploration and development work can be a problem, I have reviewed the steps leading to a public offering. I have also touched upon matters in respect of placing a

- Barrister and Solicitor, Davis \& Company, Vancouver, British Columbia.

R.S.B.C. 1960, c. 244. 
mineral property into commercial production but as indicated above this is not an area that too many will be involved in.

\section{THE MINERAL ACT OF BRITISH COLUMBIA}

This is the Act which gives a free miner the right to enter, locate, prospect and mine for all minerals held by the Crown and entitles the holder of a mineral claim to all minerals which lie within the boundaries of his claim. A free miner is defined as a person lawfully possessed of a valid Free Miner's Certificate and generally speaking, every person 18 years of age or over and every company is entitled to take out a Free Miner's Certificate.

There are basically two steps to be taken to acquire a mineral claimlocation on the ground and recording at the office of a Mining Recorder.

The procedure by which a mineral claim is located is as follows:

- A claim must be marked by two posts numbered 1 and 2 and the distance between these posts shall not exceed 1500 feet;

- The line between the posts is known as the "location line";

- Metal tags (obtained from a mining recorder) must be affixed to these posts and contain certain information regarding the claim;

- A claim may not be wider than 1500 feet and may lie entirely on either side of the location line or partly on one side and partly on the other at the option of the locator.

Once located, a mineral claim must then be recorded with the Mining Recorder of the mining division within which it is situated. The application for recording of the mineral claim must be accompanied by an affidavit of the locator and must be filed within fifteen days after the location, there being extra time given in certain circumstances, but in any event not more than thirty days after the location. This affidavit includes all the information regarding the location of the claim and in particular, it includes a free hand sketch of the claim giving the direction of the location line, position of the claim in relation to the location line and the position of the claim in relation to a topographic or man-made landmark. It is from these sketches that the Mining Recorder prepares and maintains a map showing the location of the mineral claims recorded in his mining division. These maps, which depend for their accuracy upon the ability of the Prospector, the terrain and ground cover, are the only source of information (apart from a survey of the ground) as to whether a particular claim was located over an existing claim. The Act provides that where two claims cover the same or part of the same ground the claim having the earliest location date shall take the ground common to both locations. It is obvious that the exact location of a mineral claim cannot be determined, with the result that it is almost impossible to ensure the existence of a mineral claim. There have been cases where a claim shown on a Mining Recorder's map as lying to the west of another claim in fact covered the same ground or was located to the east of it.

The only way to ensure the existence of a mineral claim is to have it surveyed by a Provincial Land Surveyor. This is a relatively costly procedure as normally a number of mineral claims are involved. Most owners defer surveying until applying for a lease of their mineral claims, one of the prerequisites of which is a survey. An alternative to a full survey of a group of mineral claims is a survey of only the key claim or 
claims to definitely establish their existence and location. Such a survey will also give some indication as to the validity of adjoining claims.

A free miner is entitled to hold a claim for one year from the date of recording and thereafter from year to year so long as during the first year and each succeeding year the free miner does work which consists of actual exploratory or mining operations to the value of $\$ 100$ and obtains and records a certificate of the work before the anniversary of the recording of the mineral claim. The Act allows the payment to the Mining Recorder of $\$ 100$ in lieu of doing the work. If more than $\$ 100$ of work is done in any year the excess may also be recorded to cover the work requirement for future years.

A lease of a mineral claim or claims may be applied for at any time but is usually not applied for until sufficient exploratory work has been done on each claim to indicate the existence of an ore body and justify a major or intensive exploration program. The main requirements to obtain a lease are that work to the value of $\$ 500$ has been done on the claim or money paid in lieu thereof and the claims have been surveyed by a Provincial Land Surveyor. A lease is for a term of twenty-one years and is renewable. After the issue or renewal of a lease it may not be impeached in any court except upon the ground of fraud and the existence and title to the mineral claims converted to lease are thereby made certain.

The Act provides that every conveyance, bill of sale, mortgage or other document of title relating to any mineral claim or any interest therein shall be recorded with the Mining Recorder of the mining division in which the claim is situated within the same time as that prescribed for recording mineral claims. The Act goes on to provide that the failure to so record does not invalidate a document between the parties thereto but that as to third parties it shall take effect from the date of record and not from the date of the document.

The Act divides the Province into twenty-four mining divisions, each with its own Mining Recorder and one or more Sub-Mining Recorders. Documents for recording may be filed either with the Mining Recorder or a Sub-Mining Recorder and if filed with a Sub-Mining Recorder are date stamped and forwarded to the office of the Mining Recorder for recording. The Mining Recorders in Vancouver and Victoria are SubMining Recorders for all other mining divisions and accordingly documents for recording in any mining division may be filed in Vancouver and Victoria. Duplicate records for each division are also maintained in these two offices. It should be pointed out however, that when searching the record of a mineral claim it is usually best to deal directly with the Mining Recorder of the division in which the claim is situate.

I should also mention that there is in existence another type of mineral claim commonly called a Crown Granted Mineral Claim. Unlike the claims located pursuant to the Mineral Act these Crown Granted Mineral Claims are an absolute grant of the minerals which lie within the claim and are subject to forfeiture only for non-payment of taxes. There is no work requirement. These Crown Grants are recorded in the Land Registry Office for the district in which they are situate and agreements or other documents affecting them are registered in much the same way as is a land mortgage or other charge. In addition, some of the early Crown Grants of surface lots also carried the right to certain minerals lying within the lot. A mineral claim located pursuant to the Act covering 
the same ground as one of these Crown Grants would entitle the holder to only the "ungranted" minerals.

\section{THE ACQUISITION AND EXPLORATION OF MINERAL PROPERTY}

At the beginning of any "mining deal" is the acquisition of mineral claims by location, purchase or contribution to the costs of exploration.

If they are to be acquired by locating, a person with some specialized knowledge of geology-prospector, geologist or professional engineershould be contracted to locate and record the mineral claims. The arrangement may be as an employee or independent contractor in which case the so called "prospectors or prospecting agreement" will be used or it may be more of a sharing or partnership arrangement where the prospector locates the claims and his "partner" provides the funds to cover the expenses which is known as grubstaking.

Where the prospector or locator of the mineral claims is an employee or independent contractor he may or may not acquire an "interest" in the claims he locates but where a grubstake arrangement is entered into it is usually the intention that the prospector will earn an "interest" in the claims. Although this "interest" may be a direct interest, it is more often a right to a percentage of the consideration received on a sale or other disposition of the claims. To a certain extent the intended method of exploration and development will govern the arrangement made. For example, most companies which intend to explore and develop claims privately do not want to hold the claims jointly or to be involved in a profit sharing or other scheme with a stranger. On the other hand, if public funds are to be raised, a new company will likely be incorporated for that purpose and the "interest" of the prospector can be satisfied by way of allotment of shares in the new company.

These agreements may call for the prospecting for minerals and the location of claims over areas of interest or may direct the location of claims to cover a specifically described area of ground. The prospector may be free to prospect anywhere in the province or be directed to a specific mining division or area of a mining division.

When drawing or considering these agreements the following matters require careful definition:

1. The relationship between the parties:

(a) master and servant;

(b) independent contractor;

(c) partnership.

2. The provisions relating to Prospectors and Grubstakers contained in Section 35 of the Income Tax Act. ${ }^{2}$

3. The scope of authority vested in a party to the agreement to deal with the property acquired so that future development will not be hampered.

2 Although prospecting is not defined by the Act it has received judicial interpretation by the Courts. It has been held that staking alone does not constitute prospecting and that in order to come within the Section the claims must be acquired as a result of the prospector's efforts as a prospector before he acquired the claims. It would appear that the following methods of acquisition of claims would not bring a prospector within the Section:

(a) staking claims through participation in a staking rush-in a "hot" geological area;

(b) staking claims on the basis of published reports-a "geological bet";

(c) staking a known mineral showing the moment it comes open for staking. 
4. The interest of each party to the agreement as to:

(a) salary and expenses;

(b) and/or a direct interest in the property and whether the interest is assessable or non-assessable;

(c) and/or a percentage of the Vendor's consideration on a disposition.

5. The party in whose name the claims are to be recorded.

6. Rights of the parties in respect of the acquisition of an interest in claims adjoining those located pursuant to the agreement.

7. The reporting required of the prospector or locator.

8. The covenant of confidentiality.

9. The term or period of the agreement.

The alternatives to acquiring claims by location can in a general way be divided into two categories: those being an acquisition for cash or, an acquisition for or in consideration of doing exploration work. In the latter category the interest acquired may be a direct beneficial interest in the claims, an indirect interest by way of the ownership of shares in the company owing the claims, or an interest or right to a share of the net profits arising on the sale or disposal of the minerals won from the claims.

Most agreements are in the form of an option with annual cash payments or work commitments spread over a period of time up to ten or fifteen years with relatively small amounts of money being paid in earlier years. The purpose of this form of agreement is to enable the "purchaser" to carry out exploration work and start an evaluation of the property concurrently with the making of his "purchase" commitment. Obviously the agreement must give the "purchaser" complete control of the mineral property in order that he may carry out this exploration and evaluation program.

In spite of the digression it might be helpful to describe briefly the types of exploration work and the order of performance and to indicate the range of the cost of an exploration program taken to the point of determining the feasibility of placing the claims into commercial production:

1. Geological, geophysical and geochemical surveys, some of which may be carried out by airborne equipment and others carried out on the ground;

2. Hand sampling-breaking off of rock from outcrops and analyzing by visual inspection or laboratory analysis;

3. Stripping-cleaning of overburden down to bedrock usually by bulldozer;

4. Trenching-removing of rock samples by hand or blasting in a regular pattern across a rock face. Usually much larger samples are obtained than by "hand sampling" and analysis is usually by an independent laboratory;

5. Diamond drilling of isolated holes with small or large diameter drills;

6. Diamond drilling on a regular grid pattern;

7. Bulk sampling-by pilot mill;

8. Independent engineering study of all data to determine feasibility of production.

Depending upon the location and size of the property, type of mineral occurrence, available information, accessibility, weather and many other 
factors, the exploration program in the first year may range in cost from $\$ 20,000$ to $\$ 100,000$. In successive years larger annual costs are usually incurred.

The total cost to complete the exploration and to determine feasibility of commercial production will vary from a low in the range of $\$ 1,000,000$ to a high in the range of $\$ 4,000,000$.

\section{AGREEMENTS}

With this brief background, a review of the main types of agreements for the acquisition of an interest in mineral claims is in order.

In the case of a sale for cash the purchase price will be payable in annual instalments commencing with relatively small amounts and increasing over the life of the agreement. The payment of instalments of the purchase price is at the option of the purchaser and the payment of each instalment will be determined to a large extent by the results of the exploration to that time. As further work is done and, assuming favourable results, more is known about the property, its value is increasing and the payment of larger instalments can be justified. If the results are unfavourable no further payments will be made and the agreement will terminate usually without the purchaser retaining or earning any interest in the claims.

It is unusual for an owner to want to sell the whole of his interest and these agreements not uncommonly provide for a royalty payment calculated as a percentage of net profits or a percentage of net smelter returns. An equity may also be retained as an undivided non-assessable interest in the claims. If the vendor retains an equity, care must be taken to ensure that the purchaser has the sole right and authority to deal with the property in all circumstances. A retained interest in a cash purchase arrangement does not usually exceed $5 \%$ of net profits.

Instead of acquiring an interest for cash, a "purchaser" may agree to do a certain amount of exploration work to earn his interest. Like the cash purchase agreement the total amount to be spent on exploration is usually divided into amounts to be spent annually with those for the first few years being relatively small and those for the last years substantially greater. Although the making of any expenditure is at the option of the "purchaser" and will of course be based upon the results of the previous work, these agreements usually require that if the "purchaser" has made the expenditures required for one year and wishes to proceed with the work for the next year he must commit himself to spend the full amount set for that year. In this way the vendor knows at the beginning of each year whether the agreement is to be proceeded with or not and, more importantly, that if proceeded with a certain minimum amount of work will be carried out on his mineral property during the year.

Because the interest is being earned by the doing of work and the owner is likely not receiving any payment, the amount of the interest to be earned will vary in the $40 \%-80 \%$ range and depend largely upon the stage of development of the property at the time the agreement is made and the amount of work agreed to be done to earn the interest.

When drawing or reviewing these agreements the following matters should be defined with care: 
1. Covenant as to title, date to which claims are in good standing and the encumbrances attaching thereto if any;

2. Right to enter, explore and develop the property;

3. (a) Obligation to carry out exploration work or to pay instalments of the purchase price,

(b) Right to accelerate exploration or prepay purchase price,

(c) Acceleration of payments of purchase price on placing the claims in production;

4. Obligation to record work and maintain claims in good standing free of liens;

5. Right to relocate claims, surrender or return unwanted claims to owner and to convert claims to lease;

6. (a) Delivery of reports on work done,

(b) Right to inspect work,

(c) Covenant of confidentiality;

7. Allotment or sale of shares other than to optionee pursuant to agreement;

8. The right to raise funds for the operation and administration of the vendor company;

9. Management of vendor company-time of change-right to appoint Directors-expenditure control by financier;

10. Rights of parties where an interest is acquired by one of the parties in mineral claims within a two mile radius of those claims, which are the subject of the agreement;

11. Right of termination;

12. Right to remove equipment.

Most of the exploration-work agreements also deal with production and give the "purchaser" or optionee the right to decide whether or not to place the property into commercial production.

The cost of placing a property into production, excluding all exploration costs but including milling facilities, supply of water, removal of overburden, housing, concentrating facilities, tailings or waste disposal, roads, administration and engineering is substantial and will range from a few million dollars to as much as a hundred million dollars in the case of a large "open pit" mine.

In some cases the optionee, having decided on production, has the obligation of providing or acquiring the necessary funds and carrying out the work to equip the claims for production. As consideration for this work the optionee will be entitled to an increased interest in the claims. In other cases, although the production decision remains the optionee's, the vendor will have the right to provide its share of the necessary funds and, if provided, the vendor's retained or remaining interest in the claims will not be further reduced.

A third type of agreement is one by which the "purchaser" or operator acquires the right to a percentage of the net profits from production in consideration of placing the claims into production. In this agreement the operator acquires no interest, direct or indirect, in the claims but is simply granted the right to explore and develop and to place the claims into production. To ensure that the operator maintains a satisfactory exploration and development program these agreements usually contain a time limit within which production must commence, or require annual payments to be made to the owner prior to production, 
which payments are credited against future royalty or other payments due to the owner out of net profits, or require minimum annual exploration and development expenditures.

When considering an agreement which gives the right to place mineral claims into production, the following matters require careful definition:

1. Commercial production;

2. Capacity of milling facilities with a view to cost and revenue from mill use in treating ores from other properties;

3. Rights to retard or suspend production if the projected operation is uneconomic;

4. Right to dispose of production;

5. Provision for method of repayment of some or all of the costs of exploring, developing and equipping for production (usually out of $90-100 \%$ of gross receipts less operating expenses);

6. Accounting to owner;

7. Provision for a method of distribution of net profits.

\section{SOURCE OF FUNDS FOR EXPLORATION WORK}

Concurrent with the acquisition of the property, consideration must be given to the source of the funds for the "purchase". They may either be put up by the "purchaser" or raised from others. Where the funds are coming from others, a syndicate or company will usually be formed, in each case the members thereof providing the necessary funds.

A syndicate is not frequently used and when used does not usually survive past the preliminary stage, the reason being that as the financial needs of an exploration program increase, the resources of a few syndicate members are not usually sufficient. At this stage the property of the syndicate is transferred to a company to be used as the next vehicle for raising further funds.

The steps to raise funds from others using a company are generally as follows.

\section{Incorporation}

It is recommended that a private company be incorporated with a capital of not less than $3,000,000$ shares. This may either be $3,000,000$ shares without nominal or par value or an authorized capital of $\$ 1,500,000$ divided into 3,000,000 shares with a par value of $50 \uparrow$ each. The reason for incorporating a private rather than public company is that the private company can take advantage of an exemption in the Securities Act. ${ }^{3}$ This exemption is discussed in Item $3(a)$ below. The minimum capitalization of 3,000,000 shares is required if the maximum share consideration as allowed by the B.C. Securities Commission is to be taken for the transfer of the mineral property to the company.

The promoters of the company should incorporate it soon after making arrangements for the acquisition of a mineral property so that all expenditures to be made by them or their associates can be channelled through the company for shares.

2. Transferring property or option to the company

Having incorporated the company the property can then be trans-

s.B.C. 1967 , c. 45. 
ferred for a maximum consideration (assuming the company has the minimum capital requirements) of 750,000 shares. If the company does not have the minimum capitalization the number of shares which may be allotted will be reduced.

The shares allotted for the mineral property must be escrowed to the order of the Superintendent of Brokers prior to the Company converting to a public company. The Securities Commission has set the form of escrow agreement which is acceptable to it. Releases of shares from escrow will only be made after the company has carried out exploration work on the property and has filed an engineer's report on the work done and a Statement of Source and Application of Funds. The policy with regard to the number of shares to be released is not definite. However, two guidelines are that on each release of shares from escrow the number released will be either $15 \%$ of the original number of shares allotted for the property or one share for each four shares sold to the public. In the ordinary course once a mineral property is proven to contain an economic ore body all of the shares allotted for that property will be released from escrow.

\section{3(a) Raising funds for preliminary expenses including costs of incorporation, engineer's report, prospectus}

The next step is to raise at least sufficient money to pay for the costs of incorporation; for a report on the mineral property prepared by a consulting engineer; for audited financial statements and for the preparation, filing and printing of a prospectus. These funds may be provided entirely by the promotors or together with others by the sale of shares of the company. Although the Securities Act generally prohibits the sale of shares unless the issuer is registered and has filed a prospectus there is an exemption contained in section $21(2)(\mathrm{m})$ which in effect allows the sale of securities of a private company by a director of the company to relatives, close personal friends or business associates. The usual price at which the first shares of a company are sold ranges between $\$ 0.10$ and $\$ 0.25$ per share. A price below $\$ 0.10$ will not usually be approved by the Securities Commission.

\section{(b) Alternative to 3(a) raising funds for 3(a) items and for the first} phase of the program recommended in the engineer's report

In addition to the minimum funds to be raised as referred to in (a) above, it may be decided also to raise funds which are sufficient to carry out the first phase of the exploration program. Again, these funds may be provided by the promoters or others on the same basis as the first funds were raised. If these additional funds are not raised until after the engineer's report is obtained, it may be desirable to increase the price per share. This increased price can be justified on the basis that the company is now fully organized and that an engineer's report has been obtained which supplies some information about the company's mineral property. In addition, the increased price will reduce the dilution of the original 750,000 shares issued for the property and the shares sold to raise the initial funds. The advantage of raising these funds "privately" is that additional shares can be acquired by the "inside" group at a low price. The disadvantage is that the inside group is gambling with their money and not the public's.

Prior to the company being converted to a public company all shares of the company not escrowed must be "pooled" pursuant to a "pooling 
agreement". These shares will not be released from the terms of the pooling agreement until thirty days after the completion of the primary distribution to the public of the company's shares. In most cases an application made for the release of the pooled shares after this time limit will be approved.

\section{Filing prospectus, selling shares, carrying out the program}

Having completed the matters referred to in $3(a)$ or $(b)$, the next step is to convert the company to a public company and file a prospectus covering an offer of the company's shares to the public. In determining the number of shares to be offered to the public and the price per share, two matters must be borne in mind. First, the Securities Commission's present policy is that it will only accept a prospectus if there is a demonstrated need for the funds to be raised. For example, if an engineer has recommended an exploration program at $\$ 50,000$, the management of the company estimates the administrative needs of the company to be $\$ 10,000$, the estimated cost of filing the company's prospectus is $\$ 3,000$, and the company's accounts payable total $\$ 7,000$, there is a demonstrated need for $\$ 70,000$ less any cash which the company may have on hand. Second, in order to have the shares of the company either called for trading on the over-the-counter market or listed and posted for trading on the Interim Section of the Vancouver Stock Exchange the company must have sold to the public pursuant to a prospectus or prospectuses not less than 250,000 shares.

Having completed the sale of the shares offered pursuant to the prospectus, the company may apply either to have its shares called for trading on the over-the-counter market or to have them listed and posted for trading on the Interim Section of the Vancouver Stock Exchange. The requirements for approval of either application are essentially the same, the three main requirements being:

(a) the company must have completed one or more primary distributions totalling not less than 250,000 shares;

(b) the company must have of record at least 125 shareholders resident in British Columbia and/or the Yukon Territory as a result of the primary distribution; and

(c) the company must have sufficient funds in its treasury to carry out the recommendations of its engineers or, if at the time of application it is in the process of carrying out the recommended work, it must have sufficient funds to complete it.

The main difference between the over-the-counter market and interim listing is that further public financing by companies whose shares are on the over-the-counter market must be done by prospectus whereas companies whose shares are interim listed are to a substantial extent governed by the rules of the Vancouver Stock Exchange and further public offerings are made pursuant to a Statement of Material Facts which is usually a much faster procedure.

Either before or shortly after the acquisition of the mineral property it will be necessary to have an exploration program prepared. This should be prepared by a mining engineer or geologist either as an employee or where public funds are to be used, by a consulting engineer. The work itself may be carried out by employees or an independent contractor. If the latter is used a contract should be drawn, preferably in consultation with the engineer or geologist preparing the program. 


\section{Raising of further funds}

Once the first exploration program is completed a second program will be prepared and further funds raised and so on until the property is either abandoned or placed in production.

\section{CONCLUSIONS}

The foregoing is a very brief description of the steps which may be taken and some of the more important matters to be considered in relation to the acquisition and development of a mineral property. At best it can be considered only as a guide. Every "mining deal" begins and develops differently, each property is of a different size and location and bears differing minerals in varying types of occurrences. Each arrangement and agreement in any "mining deal" must be designed to fit the type of property and the resources and needs of the parties. 